\title{
Experts Consensus on the Items of Sender in Communication of Malaysian Polygamous Muslim Couples Using the Delphi Fuzzy Method
}

Salasiah Hanin Hamjah, Zulkefli Aini, Mariam Abd Majid, Muhammad Yusuf Marlon Abdullah, Sahlawati Abu Bakar, Mohd Ridhuan Mohd Jamil, Naqibah Mansor

To Link this Article: http://dx.doi.org/10.6007/IJARBSS/v11-i4/9827

DOI:10.6007/IJARBSS/v11-i4/9827

Received: 24 February 2021, Revised: 26 March 2021, Accepted: 16 April 2021

Published Online: 30 April 2021

In-Text Citation: (Hamjah et al., 20211)

To Cite this Article: Hamjah, S. H., Aini, Z., Majid, M. A., Abdullah, M. Y. M., Bakar, S. A., Jamil, M. R. M., \& Mansor, N. (20211). Experts Consensus on the Items of Sender in Communication of Malaysian Polygamous Muslim Couples Using the Delphi Fuzzy Method. International Journal of Academic Research in Business and Social Sciences, 11(4), 1329-1348.

Copyright: (c) 2021 The Author(s)

Published by Human Resource Management Academic Research Society (www.hrmars.com)

This article is published under the Creative Commons Attribution (CC BY 4.0) license. Anyone may reproduce, distribute, translate and create derivative works of this article (for both commercial and non-commercial purposes), subject to full attribution to the original publication and authors. The full terms of this license may be seen at: $\underline{\text { http://creativecommons.org/licences/by/4.0/legalcode }}$

Vol. 11, No. 4, 2021, Pg. 1329 - 1348 


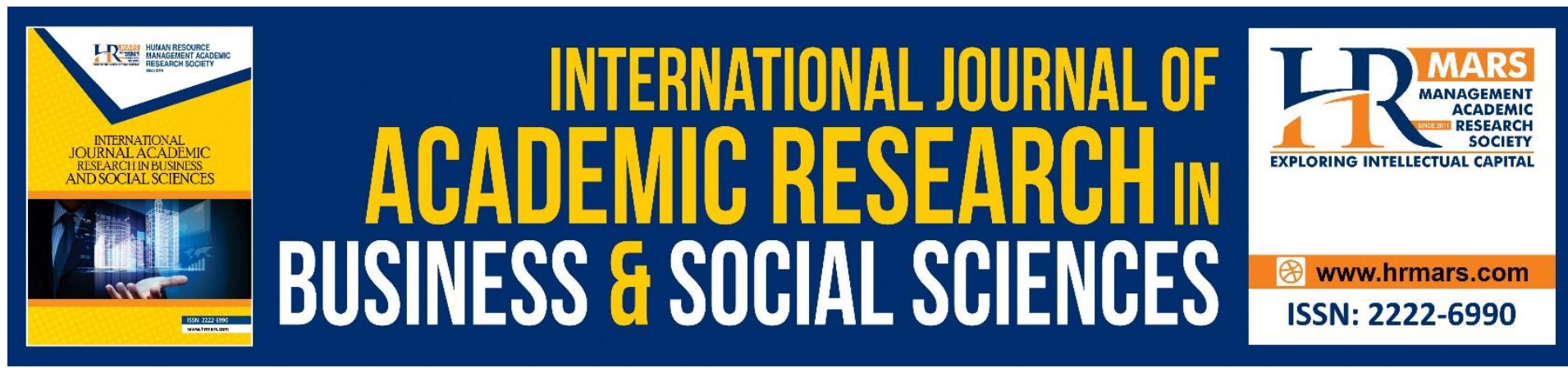

\title{
Experts Consensus on the Items of Sender in Communication of Malaysian Polygamous Muslim Couples Using the Delphi Fuzzy Method
}

\section{Salasiah Hanin Hamjah ${ }^{1}$, Zulkefli Aini ${ }^{1}$, Mariam Abd Majid², Muhammad Yusuf Marlon Abdullah², Sahlawati Abu Bakar², Mohd Ridhuan Mohd Jamil ${ }^{3}$, Naqibah Mansor ${ }^{2}$}

${ }^{1}$ Faculty of Islamic Studies, Universiti Kebangsaan Malaysia (UKM), Bangi Selangor, Malaysia, ${ }^{2}$ Faculty of Islamic Civilization Studies, Kolej Universiti Islam Antarabangsa Selangor, Bandar

Seri Putra Selangor, Malaysia, ${ }^{3}$ Center of Research and Innovation, Politeknik Nilai,

Kompleks Pendidikan Nilai, Bandar Enstek, Labu, Negeri Sembilan, Malaysia.

\begin{abstract}
A sender plays an important role in family communication especially among polygamous couples. An ineffective sender who conveys a message may cause misunderstanding, confusion and disappointment. This matter if left to persist may bring worse problems such as divorce, fights and abuses. Therefore, this article presents the consensus of experts on items categorized as sender element in the psychology of communication for co-wives in polygamous marriage in managing marital or household conflict according to the Islamic perspective. This is an important fact to produce the reliable and creative exploration of ideas of suitable information for decision making especially to polygamous Muslim couples in Malaysia in order to create better life in their family. From past highlights, 25 items have been identified as sender element. This research uses 7 point Likert scale to determine the suitability of items based on the consensus of experts. The items are evaluated by 10 experts. Data collected is analyzed using Fuzzy Delphi methodology. Research result based on consensus of experts finds that out of 25 items, one is rejected because it does not fulfill requirements. It is rejected because the threshold value exceeds 0.2 and expert percentage is less than $75 \%$. The remaining 24 items show consensus of experts on the sender element in this model. This research finding is beneficial as reference for families in order to manage marital conflict in polygamous marriages.
\end{abstract}

Keywords: Communication, Fuzzy Delphi, Polygamous, Psychology, Sender

\section{Introduction}

While a marital monogamy is highlighted as ideal and practice in traditional system of marriage (Green et al., 2015), undoubtedly 85 per cent of society in the anthropological record permit men to marry multiple wives (Henrich et al., 2012). It is recorded that people 
in the Middle East, North Africa, Eastern Asia, some communities in Europe and North America are practicing polygamous marriage (Al-Krenawi et al., 2006). In fact, the term polygamy, etymologically derived from the Late Greek word polugamos, which literally means 'often marrying' (Jonas, 2012). It is a combination of two words, i.e poly or polus, which means many, and gamein or gamos, which means marriage (Nasution, 1996). In popular speech, it usually refers to marital relationship between a man and more than one wife at the same time. However, according to Jonas (2012), this meaning is technically incorrect. The term polygamy, in its correct and wide sense especially in anthropological studies, refers to a marriage involving more than one partner (Koktevdgaard, 2008; Marzuki, 1996; Al-Krenawi et al., 1997). Generally, it consists of three forms, namely polygyny, polyandry, and polygyandry. Polygyny, the most common practice worldwide, refers to a marriage involving a husband who has two or more wives at a time. However, as a subject of present study, the term polygamy is widely used although its meaning is more general compared to the term polygyny (The Encyclopedia Americana, 1980). Polyandry is one wife married to two or more husbands. Meanwhile, polygyandry is a group marriage scenario in which two or more wives are simultaneously married to two or more husbands. From an Islamic point of view, only the practice of monogamy and polygyny are permitted. In term of polygyny, it is allowed as far as some requirements that need to be fulfilled such as the limitation of numbers of wives who can be married, which restricted only four as stated in the Holy Quran (Surah al-Nisa', 4: 3), and a husband can behave justly and equally to his wives in all aspects such as material fulfillment, living place, and family time sharing (Abdullah, 1997, 2014; Husain et al., 2019). Otherwise it does not recommended and obligated people to do.

In fact, communication is one of the most important aspects of satisfying marriage as well maintaining well-being and happiness within the interaction of each family member. Basically, there are several major elements of communication process. These are sender, ideas, communication channel, receiver and feedback. Communication involves some important elements such as sender, communicator, the recipient, the message and the medium of delivery (Shannon \& Weaver, 1949; Schramm, 1954; Berlo, 1960). One of two common and important elements in every communication exchange is the sender. The sender initiates the communication. He or she is a person who has a need or desire to convey an idea to others. In communication, the presenter is the main character that needs attention because the good or bad implications of communication are largely dependent on the speaker. Simply put, communicators or presenters are important individuals in communication. A presenter should focus on delivering the message to the recipient (Krauss \& Fussell, 1996) so that the message delivered as the presenter intended. Therefore, sender should convey the ideas very precisely with the receiver. Not only that, his idea should be concise and to the point. He has to use a softer tone and his own sensory stimuli in order to deliver ideas (Marx, 1976). Senders should have the meaningful and accurate ideas based on facts and figures in order to share with receiver (Radford, 1993).

From an Islamic perspective, sender plays important role in the communication process in terms of delivering useful ideas to receiver in accordance with Islamic principle stated in the Holy al-Quran (Surah Ali 'Imran, 3: 104) i.e calling to all that is good and spreading Islam, enjoining what is right and forbidding evil. Undoubtedly, the Prophet Muhammad is a great example of communicator in the history of human civilization who was known by his sublime character such as brilliant, honest, trustworthy and truthful in nature (Mohamed Ariffin, 2007; Wazir et al., 2015). 
One of the qualities of good communicator, from Islamic point of view, is determined by his absolute truthfulness in delivering ideas to others in order to build trust in a respective interaction between them. Therefore, if someone tends to speak lies, consequently nobody will listen to him. Not only that, it will jeopardize the trust in the relationship. Besides that, as a good communicator, sender has to be the most influential people dealing with others, so that he becomes the source of inspiration in life especially promoting and doing good deeds. This situation can be applied to the field of $d a^{\prime}$ wah or the preaching of Islam (Waizul Qarni et al., 2019).

In addition, Islam emphasizes other characteristics of good sender such as humility, kindness, justice, honesty, sincerity, intention, and ability to verify the source of the message as well as to inquire into its truth. Empathy also be applied in the process of communication where someone who is empathic has the ability to put himself in someone else's situation as well as to understand the feelings of others (Nuzula, 2015; Sarji, 1985). Not only that, communication will be successful and effective when both the person sending the message and the person receiving it understand the key messages being put across. Basically, listeners appreciate a little humor even in a serious speech. Therefore in the context of $d a^{\prime} w a h$, the preacher as a source of message will employ humor effectively in his speech. Humor, however, should accentuate our communication, not dominate it. That is why when the preachers fill others' mind with as several hilarious anecdotes and stories as possible, they could create a harmonious situation among receivers and make them happy in life (Yaakob et al., 2018; Wan Mansor, 2014). Being a good communicator should be a key agenda for every couple so that each message delivered has the value of accuracy, truth, goodness, justice, honesty, humility, serenity, fun and glory. This discussion clearly demonstrates the importance of presenters having the knowledge to improve communication effectiveness because effective communication is crucial to enhancing harmony, health and happiness in the home and family (Muňiz \& Álvarez, 2013; Chan et al., 2012; Apolinara et.al., 2011).

\section{Literature Review}

Many studies on polygamy or polygyny have been conducted. Most of the findings are about the effects of polygamous marriage on wives, children and husbands. Among the negative effects that children have on polygamous marriage such as emotional stress (Alhuzail, 2020), mental health problems, social problems and low academic achievement (Al-Sharfi et.al., 2016; Al-Krenawi \& Slonim, 2008). In addition, polygamy has negative effects on wives such as stress (Farahmand \& Rezvani, 2019), abuse (Thobejane \& Flora 2014; Rafeah et al., 2017), problems in family functioning, marital relationships, low self-esteem, dissatisfaction with marriage, depression, anxiety, paranoid, psychotic (Al-Krenawi et al., 2011), impact on quality of life, ongoing conflict with wives and attitude of loving and neglectful husband (Gumani \& Sodi, 2009).

Although previous research shows that polygamous marriages have negative effects, there are some studies that have found that polygamy has positive effects on families such as happiness (Thobejane \& Flora, 2014), increasing the birth rate due to competition between spouses for childbirth because they believe their husbands love many children (Rossi, 2019) and reduce divorce (Gumani \& Sodi, 2009; Khasawneh et al., 2011). In addition, a study conducted by Ekerbiçer et al. (2016) found that polygamy was recognized to have a positive effect on men. Men who practice polygamy are less likely to suffer from depression than men who practice monogamy. The study also found that there were a number of factors that caused a man to remarry, including a decline in sexual satisfaction by the first wife $(37.1 \%)$, 
love for the second wife (22.8\%) and incompatibility with the first wife (17.1\%). However, $62.9 \%$ of them disagree with proposing polygamy to another man.

Polygamy has also been shown to have a positive effect on both wives and children when the husband or father is performing well. The wives claim that the husband provides education, a home for children and family expenses. They show great comfort because of the financial support and fairness shown by the husband. Children can also accept polygamy because their parents are fair (Khasawneh et al., 2011). The discussion on pros and cons of polygamy is too broad. Therefore polygamy can have a positive effect if the husband is fair and fulfills the requirements set forth in Islamic law. These requirements are outlined to protect the welfare and rights of wives and children. Benkheira (2019) in the study found that although polygamy practices depict men having the power to marry more than one person, the man has to adhere to Islamic law by fulfilling the requirements. However, in Malaysia, Abdullah and Khairuddin (2009) rightly highlighted that the right to practice polygamy was no longer the unilateral prerogative of the husband but based on a judicial decision of the Syariah Court. Therefore, a man who wishes to marry an additional wife must submit an application to the Syariah Court in accordance with Islamic law enactment (Abdullah, 2014; Abdullah \& Khairuddin, 2009; Hak, 2008). In Malaysian context, Section 23(4) of Islamic Family Law (State of Selangor) Enactment 2003, for example, firmly states that an application for permission shall be submitted to the Court and accompanied by an iqrar or declaration and admission stating the grounds on which the proposed marriage is just and necessary.

Previous studies have shown many negative effects of polygamous marriages on wives and children. Therefore, a study was conducted to suggest a solution to this problem. For example, the study of Ault and Gilder (2016) described structural theory as applicable to polygamous marriages to restructure the role of family members and adapt them by changing family membership so that family harmony can be maintained. Lander's (2014) study found that forgiveness (forgiveness) therapy is one of the practical approaches to be practiced in a polygamous family to maintain harmony. In addition, the study of Slonim and Al-Krenawi (2006) found that various ways can be done to overcome the problem of polygamous marriages such as wives accepting polygamy as God's destiny, equitable provision by husband to each family, separation between the two households and maintaining respect for the other wife. In short, many studies have been conducted on polygamy and it is seen from many angles that it is illustrated that polygamy is practiced in the world especially in countries which are populated by Muslims. In addition to the issue of polygamy, this study also discusses family communication. Studies on family communication have also been conducted. Among them are the study of Nur Wahidah (2011), Ali, Md. Rahim and Mustaffa (2008), Apolinaras, Nida and Jovita (2011), Che Noh and Yusooff (2011), Honeycutt (1993) who found in their study that communication plays an important role in marriage and family life. In fact, happiness and divorce are said to have a significant relationship with communication.

Many studies have shown that communication problems can trigger divorce (Thompson, 2008; Honeycutt, 1993; Thomas et al., 1995; Ismail, 2016). Family communication problems can also cause many other problems such as abuse and frustration (Xue et al., 2018; Thompson, 2008; O'Shay, 2020). In addition, communication problems are also associated with quarrels, misunderstandings and quarrels (Che Noh \& Yusooff, 2011; Xue et al., 2018; Pickover et al., 2019). This previous study shows that communication problems often occur in monogamous families. There are not many studies examining communication problems in polygamous families but this is an important point to study as polygamous marriages involve 
more members of the family who may have different attitudes, stances and backgrounds and may need to adapt to more challenging communication processes.

This study also examines the psychological aspects of communication because communication involves psychological elements. Previous studies have discussed this as the study of Nikmah (2011) that explains psychology of communication is one of the branches of communication research that discusses how understanding of psychology can make the delivery process more effective. Communication that involves psychological elements can enhance social relationships, strengthen one another, make good decisions, and solve problems. In addition, Ponomaryov et al. (2016) explain important psychological aspects of communication to produce effective communication that incorporates a set of skills including nonverbal communication, attentive listening, stress management ability, ability to recognize and understand one's emotions.

In this context, many studies linking psychology and communication such as McCarthy, Trace and O'Donovan (2014) and Buhlmann (2010) have found that there is a need to combine teaching, learning and assessment of applied psychology with interpersonal communication skills in nursing education. Similarly, Strzalka's (2016) study also found that there is a need to integrate communication and psychology in language-related education to provide motivation and fun learning. In addition, the study of Xia (2014) found that there is a link between college students' communication patterns and psychological health. These studies clearly indicate the importance of a student's knowledge of communication psychology for their future careers.

Studies on the psychology of communication in the family have also been conducted. Among the studies that touch on this aspect is a study by Armas (2018) that explores aspects of parental communication patterns that influence children's psychology, especially on emotion and self- esteem. Sumakul's (2015) study examined the role of parental communication in the formation of children's self-identity. Che Noh's (2006) study found that there is a link between parenting style and children's personality. Correlation analysis showed that extrovert personalities were significantly associated with authoritative parenting style. The findings of this study indicate that communication has a strong relationship with psychology. Therefore, there is a great need for research in this area to improve communication skills and provide psychological well-being for the whole family.

Based on this discussion, it is clear that studies of polygamy, family communication, and psychology of communication have been conducted. However, no studies on the psychology of communication among polygamous couples have been conducted especially by examining the aspects of communication, what to say and what should not be conveyed to polygamous couples. Therefore, this study aimed to identify the presenter's items in the communication of polygamous couples by obtaining expert consensus to provide knowledge and guidance in delivering a message when communicating so that they can choose the right, accurate and appropriate words when communicating to reduce conflict and maintain harmony.

\section{Research Objective}

- Objective of the research is to identify items which are categorized as communicative elements in the psychology of polygamous communication based on expert consensus.

\section{Research Questions}


Are the items categorized as communicative elements in the psychology of polygamous communication based on expert consensus?

\section{Research Method}

\section{Research Design}

This study used the Fuzzy Delphi technique for the purpose of obtaining expert consensus on the items contained in the communicative elements in communication psychology developed based on the literature sample.

The analysis of the study data for the Fuzzy Delphi (FDM) method is based on the conditions contained in the triangular fuzzy number. The requirements for a triangular fuzzy number involving threshold value (d) and percentage of expert agreement with threshold value (d) for each item measured must be less than or equal to 0.2 (Chen, 2000; Cheng \& Lin, 2002 ) and the percentage of expert group agreement must exceed or equal to $75 \%$ (Murry \& Hammons, 1995; Chu \& Hwang, 2008). The threshold value (d) will be analyzed using Microsoft Excel based on the following formula:

$$
d(\tilde{m}, \tilde{n})=\sqrt{\frac{1}{3}\left[\left(m_{1}-n_{1}\right)^{2}+\left(m_{2}-n_{2}\right)^{2}+\left(m_{3}-n_{3}\right)^{2}\right]} .
$$

For the process of determining the $\alpha$-cut value for the purpose of analyzing the study data, the defuzzification process is used. In this process, the authors use one of the formulas cited by Mohd Ridhuan et al., (2013) as follows:

$A=1 / 3 *(m 1+m 2+m 3)$

If the resulting $A$ value is less than the $\alpha$-cut $=0.5$ value, the item is rejected because there is no expert agreement in accepting the item. However, if the resulting $A$ value exceeds the $\alpha$-cut $=0.5$ value, the item is accepted (Tang \& Wu, 2010; Bodjanova, 2006).

In short, the requirements for reaching an expert agreement are as follows:

Table 1: Terms of Triangular Fuzzy Numbers and Defuzzification

\begin{tabular}{ll}
\hline Requirement & Value \\
\hline Threshold Value(d) & $\leq 0.2$ \\
Percentage of experts' Agreement & $\geq 75 \%$ \\
Value of $\alpha$-cut & $\geq 0.5$ \\
\hline
\end{tabular}

\section{Instrument of Study}

The instrument used was a questionnaire containing 25 items. This questionnaire is intended to identify items that are categorized as presenter elements in the psychology model of couples' communication in managing household conflict. Items contained in this element are based on the literature highlight. Subsequently, these items will be identified by distributing questionnaires that will be analyzed using the Fuzzy Delphi technique to obtain expert consensus.

All question items were answered on a 7-point Likert scale (from 1 = Extremely Inappropriate, to $7=$ Extremely Correct) as shown in Table 2 below: 
Table 2: Fuzzy scale of agreement and scale

\begin{tabular}{lll}
\hline Level of agreement & Fuzzy Scale & Likert Scale \\
\hline xtremely Not Suitable & $0.0,0.0,0.1)$ & $:$ \\
ieally Not Suitable & $0.0,0.1,0.3)$ & $\vdots$ \\
Jot Suitable & $0.1,0.3,0.5)$ & $:$ \\
Aoderately Suitable & $0.3,0.5,0.7)$ & $\vdots$ \\
uitable & $0.5,0.7,0.9)$ & $;$ \\
ieally Suitable & $0.7,0.9,1.0)$ &, \\
:xtremely Suitable & $0.9,1.0,1.0)$ &
\end{tabular}

Source: (Mohd Ridhuan et al., 2015; Rashidah et al., 2018)

Table 3 below shows the items asked by experts for the element of the presenter

Table 3: Item for Speaker's element

\section{Num Presenter Items}

1 Co-wives deliver remarks or words to each other with a firm, easy-to-understand message.

2 Co-wives need to understand how husbands communicate.

3 Co-wives interpret the message before passing it on to one another.

4 Co-wives receive every word or remark from each other in advance.

5 Co-wives need to convey the words according to the situation among themselves.

6 Co-wives have to be honest and truthful with each other.

7 Co-wives have to use good intonation with each other.

8 Co-wives need to be positive in conveying a message to each other.

9 Co-wives need to identify the authenticity of a message to convey to one another.

10 Co-wives should take precedence in making an assessment of the message that it wants to convey to one another in advance.

11 Co-wives need to be positive in conveying a message to each other.

12 Co-wives convey an idea / information / fact in a non-aggressive (fierce) way but are assertive and respect the rights and feelings of each other.

13 Co-wives deliver remarks or words to each other with a firm, easy-to-understand message.

14 Husbands need to show how to communicate with their actions.

15 Husbands interpret the message before passing it on to the wives.

16 Husband receives every word or word from the wives in advance.

17 Husbands convey words according to the situation to their wives.

18 Husbands need to be honest and truthful with their wives.

19 Husbands need to use good intonation with wives.

20 Husbands need to be positive in communicating a message to their wives.

21 Husbands need to identify the authenticity of the message they want to convey to their wives.

22 Husbands need to be bold in expressing their intentions to be polygamous to their wives. 
23 Husbands need to give priority to making an assessment of the message they want to convey to their wives.

24 Husbands need to have clear information before conveying a message to their wives.

25 Husbands convey things firmly and respect the rights and feelings of their wives.

\section{Sample of Study}

In this study, the researchers selected 10 experts involving two polygamous practitioners and two co-wives with more than 5 years experiences, two officers of Malaysian religious affairs authority (one of them is an officer from the Family Law Division of Selangor Islamic Religious Department of Malaysia or JAIS; and another is an officer from the Family, Social and Community Divisions of Department of Islamic Development Malaysia or JAKIM), and four lecturers from Public Universities in Malaysia with expertise in Islamic preaching, communication, counseling and psychology. Table 4 below shows the number of experts involved:

Table 4: Number of experts involved

\begin{tabular}{ll}
\hline Expert & Number of Expert \\
\hline Polygamy Practitioners & 2 \\
Co-wives & 2 \\
JAIS Officer & 1 \\
JAKIM Officer & 1 \\
Lecturer & 4 \\
\hline
\end{tabular}

\section{Findings}

The following is a review of the entire presenter item.

Table 5: Expert and terms of agreement for each item

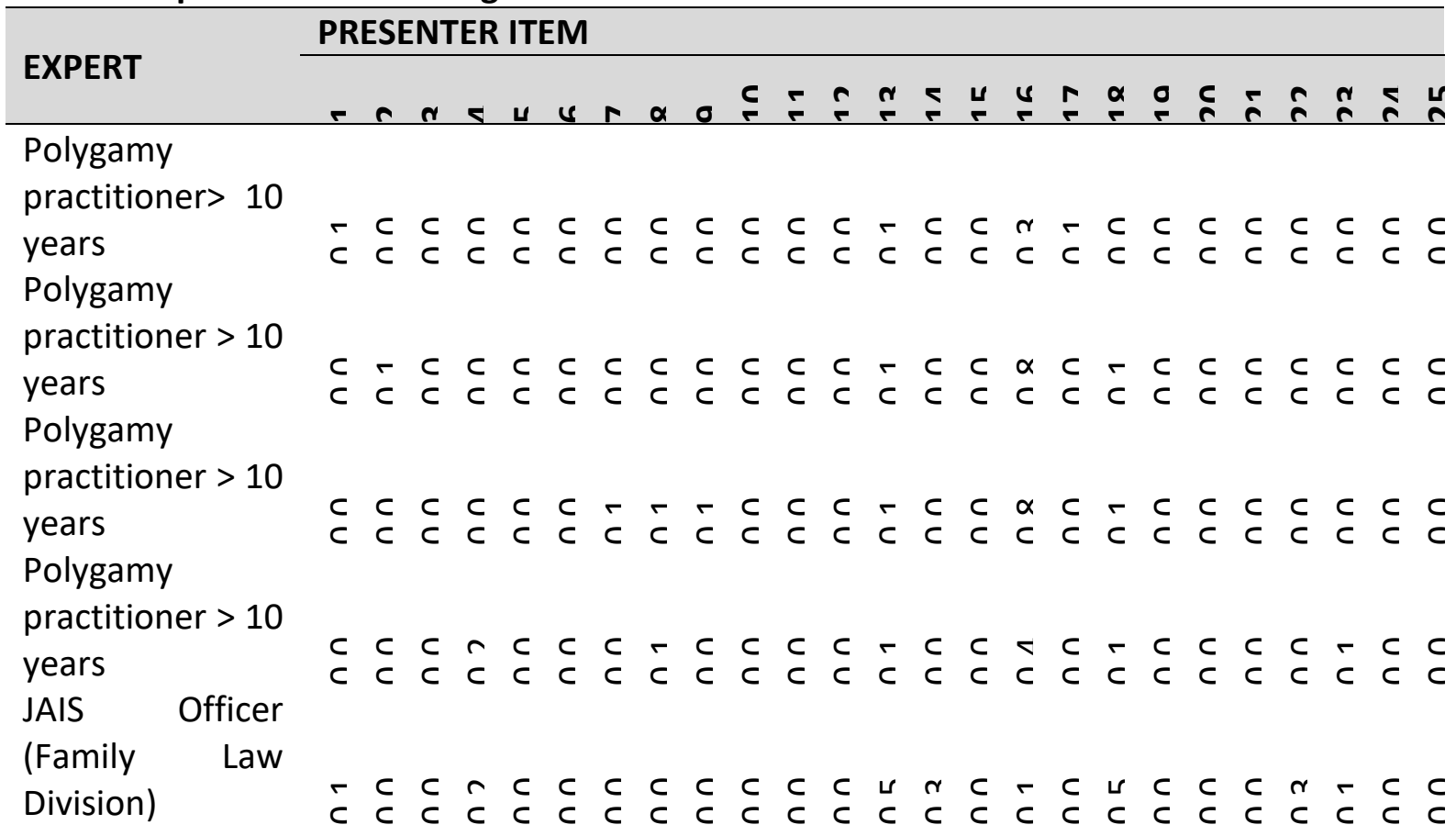




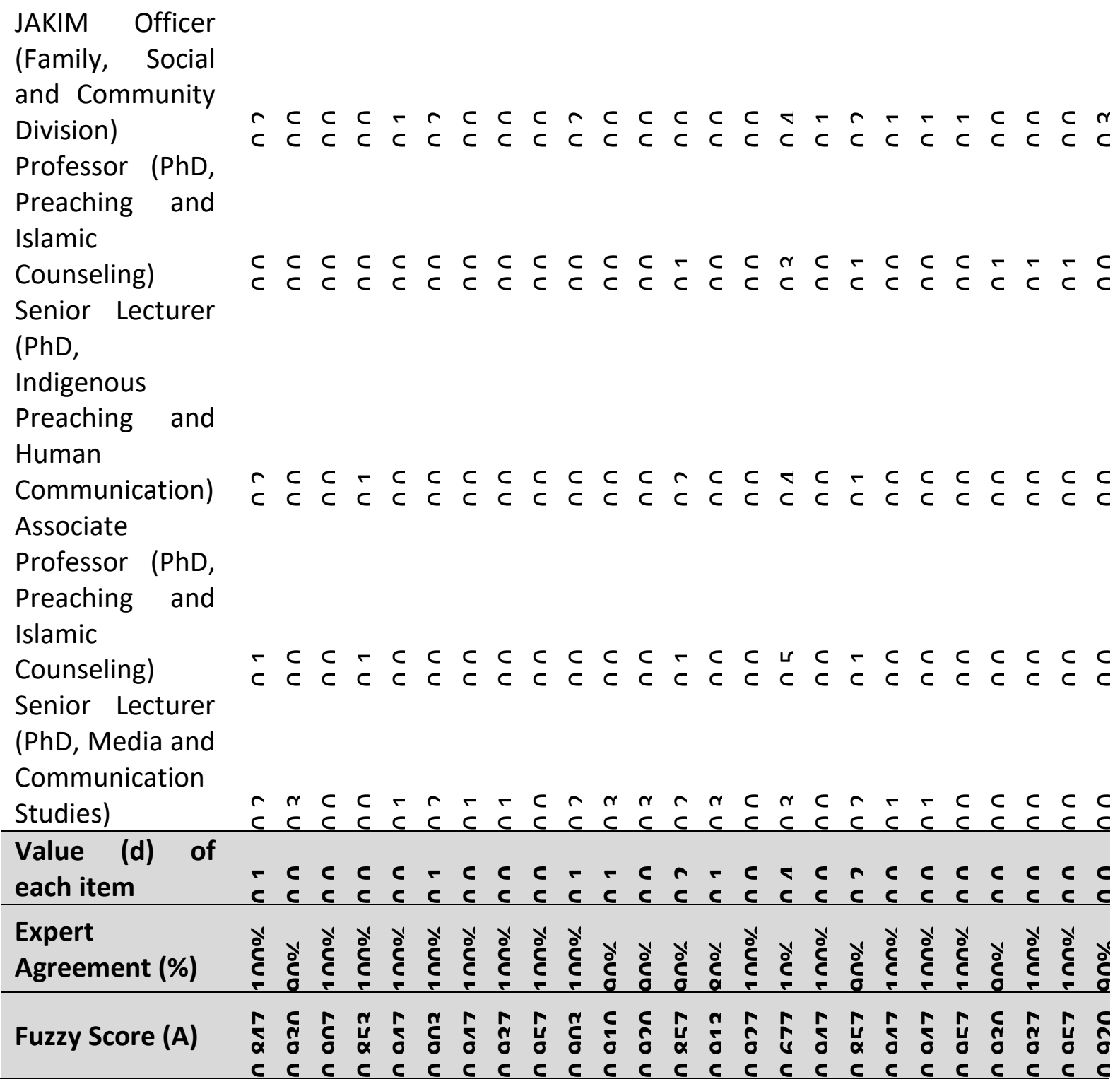

Condition 1: Threshold Value (d)

Overall, based on the threshold value (d) shows only 16 items rejected because the threshold value $(d)$ is greater than 0.2 .

\section{Condition 2: Percentage of experts' Agreement (\%)}

Overall, based on expert approval percentage indicated that only 16 items were rejected due to less than $75 \%$ of expert consensus.

\section{Condition 3: Fuzzy Score (A)}

All of the items contained in this presenter element exceed the $\alpha$-cut value required in the defuzzification process.

In conclusion, it can be said that item 16 was rejected because it failed to meet three requirements for expert consensus. 


\section{Discussion}

The results of this study found that out of 25 items, one was rejected for not meeting the requirements. This item was rejected because the threshold value was greater than 0.2 and the specialist percentage was less than $75 \%$, 'Husbands receive every word or remark from the wives first'. The remaining 24 items are acceptable as items for the conveyor component in polygamous communication.

The item 'Husband receives every word or remark from the wives first' does not get expert consent to apply in communicator communication because it raises many questions and is not well understood by the expert. This item raises the question whether a husband should receive every wife's speech? The word in advance is also confusing as what is the meaning of in advance? What comes first?

In addition, the reviewer also takes into account the expert's comments and suggestions for refinement purposes. Table 6 shows the items in the presenter element that have been obtained by the expert in the analysis using the Fuzzy Delphi technique. The bold items are items that have been refined and suggested to the researcher and have been approved by the panel of experts. 
Table 6: List of items (bold) that experts have refined and suggested

\begin{tabular}{ll}
\hline Num & Element of Conveyor Component \\
\hline 1 & $\begin{array}{l}\text { Co-wives utter words or speeches to each other with a clear, easy-to-understand } \\
\text { message. }\end{array}$ \\
3 & $\begin{array}{l}\text { Co-wives need to understand how husbands communicate. } \\
\text { Co-wives think (replacing the words 'interpret the message') before delivering the } \\
\text { message amongst them. }\end{array}$ \\
4 & $\begin{array}{l}\text { Co-wives hear (in place of the word 'receive') the words or speeches of a fellow } \\
\text { sister-wife first. }\end{array}$ \\
6 & $\begin{array}{l}\text { Co-wives need to convey the words according to the situation among themselves. } \\
7\end{array}$ \\
8 & Co-wives have to be honest and truthful with each other. \\
9 & Co-wives needs to be positive in conveying a message to each other.
\end{tabular}

10 Co-wives should take precedence in making an assessment of the message that it wants to convey to one another in advance.

11 Co-wives needs to be positive in conveying a message to each other.

12 Co-wives convey an idea / information / fact by way of wisdom (replacing the word 'not aggressive / loud but assertive') and respects the rights and feelings of each other.

13 Husbands convey words or speeches to their wives clearly (replacing the word 'firmly') with ease.

14 Husband needs to show good communication (replace the word 'along with action')

15 The husband thinks (replacing the words 'interpreting the message') before delivering the message to the wife.

16 Husbands convey words according to the situation to their wives.

17 Husbands need to speak honestly and truthfully with their wives according to circumstances and time (additional)

18 Husbands need to use good intonation with wives.

19 Husbands need to be positive in communicating a message to their wives.

20 Husbands need to identify the authenticity of the message they want to convey to their wives.

21 Husbands need to be honest about their intentions for polygamy.

22 Husbands need to give priority to making an assessment of the message they want to convey to their wives.

23 Husbands need to ensure the authenticity of the information before relaying the message to their wives.

24 Husbands convey things in a wise way (in place of the word 'firm') and respect the rights and feelings of their wives.

In general, the findings show that there are eight (8) items that experts recommend for repair, namely items $3,4,12,13,14,15,17$ and 24 . Items 3 and 15, for example, specialists recommend the "sister-wife / husband 'message interpretation' item before passing the message to the co-wives / spouse, switching to the" sister-wife / husband 'thinking' before 
delivering the message to the co-wives / spouse. Thinking before delivering a message has many advantages because it encourages one to think ahead of time whether the message to be delivered is of benefit and benefit to the person who receives it or otherwise brings sadness and disadvantage to the recipient. The urge to think before speaking has been discussed by many researchers such as Steyn (2015), and Predelli (2004).

In addition, experts also recommend the item "sister-wife 'listen' the words or speeches of fellow co-wives first" to replace the word 'receive' (item number 4). Listening skills are one of the factors that can help improve communication effectiveness. This finding is in line with Wood and Davidson's (2002) study showing that empathic listening skills can reduce stress and family conflict.

Experts also suggest that the item "sister-wife conveys an idea / information / fact in a wise and respectful way while respecting the rights and feelings among them" to replace the word 'not aggressive / fierce but assertive '(Item number 12). Similarly to item number 24, experts recommend that "husbands convey something in wisdom and respect the rights and feelings of wives" in place of the word 'firm'. The findings show that experts are more likely to choose the word wisdom rather than strictly. This shows that wisdom is better than assertive. Wisdom in Islamic perspective is known as al-Hikmah, which refers to something appropriate depending on the circumstances (Mohd. Zin, 2003), and knowing the right thing and then acting according to it as well as accuracy in speech and actions and a true knowledge which can inspire oneself to conduct a meaningful and beneficial act (Lokman \& Ibrahim, 2017). Wisdom and tact are essential in communication so that the message conveyed is appropriate and understandable and well received.

The findings of the study also show that experts recommend item number 13 changed from "Husband to convey words or speeches to wives firmly and clearly" to "Husbands convey words or speeches to wives clearly and easily". This suggests that the word firmly is not appropriate for polygamous couple communication because it is closer to authoritarian leadership style. Many studies have shown that authoritarian leadership style or conformity communication style as poorly and will affect the well-being of family members and that authoritative leadership style that promotes discussion and openness is better for the physical and mental development of families (Steinberg et al. 1994; Che Noh \& Yusoff, 2011; Ismail, 2001; Siti Marziah et al., 2019).

In addition, item number 14 is also suggested by experts to change from "Husband needs to show how to communicate along with actions" to "Husband needs to show good communication". This shows that good communication is more important than proving it by action. Good words are very important in communication to create a happy and respectful atmosphere. On the other hand, bad words can lead to divorce and family conflict. This is evident in most studies on this subject (Hamzah \& Mat Hasan., 2012; Esere, Ake \& Comfort, 2014; Fowers, 2001; Mohamad et al., 2019).

Similarly for item 17, experts recommend that the item "Husband need to be honest and truthful with wives" is changed to item "Husband should speak honestly and truthfully with wives according to circumstances and time". The addition of the words "according to time and place" is reasonable because sometimes the truth does not need to be stated if it can offend the spouse especially if it involves sensitive issues such as the physical shape of the fat partner, acne face, petite body and so on (Raja Ahmad, 2017).

Conclusions

The results showed that 24 presenter items were agreed upon and accepted upon by 10 experts for polygamous communication. The only item the expert rejected was the item 
"Husband receives every word or speech from his wife first". The other 24 items are agreed upon by experts to serve as communicative items in the communication of polygamous couples with minimal adjustments. The findings of this study can be used as a reference and guidance for polygamous couples to improve the communication between husband and wife and between polygamous marriages.

\section{Contribution of the Study}

The present study concerning experts consensus on the items of sender in communication process among Malaysian Polygamous Muslim couples using the Delphi Fuzzy Method contributes to the theoretical and contextual aspects related to the field. Theoretically, it provides knowledge how to manage conflict among Muslim couples who do practice polygamous marriage. Not only that, the study also provides some ideas to those couples to improve their communication skills in order to maintain well-being and happiness within the interaction of each family member. In addition, this should bring shining on the plight of those couples to realize the philosophy of marriage in Islamic practice namely al-sakinah (happiness), al-mawaddah (affection and love) and al-rahmah (mercy and compassion). The study also has a significant to the existing knowledge related to developing a model of an ideal polygamous Muslim couples which comprises psychological communication theory. The construction of this model contributes to the development aspect of conflict management theory among polygamous couples. Stakeholders, namely the government, agencies, and individuals can use this model in planning pre and post-marriage courses in the community.

\section{Acknowledgement}

This research was funded by the Selangor International Islamic University College (KUIS) through the Premier Research Grant (GPP), 2017 / P / GPIK / GPP / 001. This research also received a grant from the National University of Malaysia (Universiti Kebangsaan Malaysia), Project Code (KRA-2018-037). All authors were contributed in the article in terms of conceptualization, methodology, formal analysis, writing-original draft preparation, writing - review and editing, and project administration.

\section{Corresponding Author}

\section{Zulkefli Aini}

Faculty of Islamic Studies, Universiti Kebangsaan Malaysia, 43600 Bangi, Selangor, Malaysia. Email: zulaini@ukm.edu.my

\section{References}

Abdullah, R. (2014). Poligami: Penjelasan Berdasarkan Perspektif Undang-Undang Keluarga Islam di Malaysia. Putrajaya: Jabatan Kemajuan Islam Malaysia.

Abdullah, R., \& Soraya, K. (2009). The Malaysian Shari'ah Courts: Polygamy, Divorce and the Administration of Justice. Asian Women, 25(1), 21-54.

Abdullah, R. (1997). Poligami di Malaysia. Jurnal Syariah. 5(2), 167- 183.

Alhuzail, N. A. (2020). Being a Girl in a Polygamous Family Implications and Challenges. Child And Adolescent Social Work Journal. 37(1), 97-107. Doi: 10.1007/s10560-019-00623-w

Ali, A., Irkhaniza M. R., \& Mohamed, S. M. (2008). Peranan Komunikasi dalam Hubungan Kekeluargaan. Paper presented at Seminar Kaunseling Keluarga, Johor Baharu, Malaysia, August 30. 
Al-Krenawi, A., John, R. G., \& Fakir, A. G. (2011). A Comparison Study of Psychological, Family Function Marital and Life Satisfactions of Polygamous and Monogamous Women in Jordan. Community Mental Health Journal, 47(5), 594-602. Doi: 10.1007/s10597-0119405-x

Al-Krenawi, A., \& Vered, S-N. (2008). Psychosocial and Familial Functioning of Children From Polygynous and Monogamous Families. Journal of Social Psychology,148(6), 745-764. Doi: 10.3200/SOCP.148.6.745-764

Al-Krenawi, A., John, R. G., \& Sivan, B. S. J. (2006). Attitudes Toward and Reasons for Polygamy Differentiated by Gender and Age Among the Bedouin-Arab of the Negev. International Journal of Mental Health, 35(1), 46-61. Doi: 10.2753/IMH0020-7411350105

Al-Krenawi, A., John, R. G., \& Salem, A. S. (1997). Social Work Practice with Polygamous Families. Child and Adolescent Work Journal, 14(6), 445-458.

Al-Sharfi, M., Karen P., \& Kirsty A. M. (2016). The Effects of Polygamy on Children and Adolescents: a Systematic Review. Journal of Family Studies. 22(3), 272-286. [DOI: 10.1080/13229400.2015.1086405]

Apolinaras, Z., Zemaitiene, N., \& Petruskeviciute, J. (2011). Happiness and Life Satisfaction of Adolescents Related To Communication With Parents. Psychology \& Health. 26(1), 243243.

Armas-Vargas, E. (2018). Comuniatión Filio-Parental: Adaptación y Autoestia en Adolescentes (Parent-Child Communication: Adaptation and Self-Esteem in Adolescents). In Psicología Jurídica: Ciencia Y Profesión. Edited by Enrique Carbonell, David Pineda, and Meredes Novo. (pp. 219-234), Granada: Colección Psicología y Ley.

Ault, M. K., \& Bobbi, V. G. (2016). Polygamous Family Structure: How Communication Affects the Division of Household Labor. Western Journal of Communication. 80(5), 559-580. Doi: 10.1080/10570314.2016.1188327.

Benkheira, M. H. (2019). The Impossible Equity: Polygyny and Sharing of Nights. Hawwa. 17(23), 197-230. Doi: 10.1163/15692086-12341357

Berlo, D. K. (1960). The Process of Communication: An Introduction to Theory and Practice. New York: Holt, Rinehact and Winston.

Bodjanova, S. (2006). Median Alpha-Levels of a Fuzzy Number. Fuzzy Sets and Systems, 157(7), 879- 891. https://doi.org/10.1016/j.fss.2005.10.015

Buhlmann, U. (2010). Psychology and Communication for Nursing. Pflege. 23, 50-50.

Chan, S. S. C., Mui, M., Soong, C. S. S., Wong, X., \& Tai-Hingn, L. (2012). Family Communication is a Mediator to Increase Family Harmony, Happiness and Health: Findings From a Community-Based Participatory Research (CBPR) Project in Hong Kong. International Journal of Behavioral Medicine. 19(1), S288-S289.

Chen, C-T. (2000). Extensions of the TOPSIS for Group Decision-Making under Fuzzy Environment. Fuzzy Sets and Systems. 114, 1-9.

Cheng, C-H, \& Yin, L. (2002). Evaluating the Best Main Battle Tank Using Fuzzy Decision Theory with Linguistic Criteria Evaluation. European Journal of Operational Research. 142(1), 74-86.

Che Noh, C. H., \& Fatimah, Y. (2011). Corak Komunikasi Keluarga dalam Kalangan Keluarga Melayu Di Terengganu. Jurnal Hadhari. 3(2), 45-62.

Che Noh, C. H. (2006). Hubungan Keluarga dari Aspek Komunikasi dan Gaya Keibubapaan. Jurnal Kemanusiaan. 4(2), 45-57. 
Chu, H-C, \& Gwo-Jen, H. (2008). A Delphi-Based Approach to Developing Expert Systems with the Cooperation of Multiple Experts. Expert Systems with Applications. 34(28), 26-40. doi:10.1016/j.eswa.2007.05.034

Din, N @ M. N., Nurzatil, A., Nazneen, I., \& Ahmad, Z. A. (2014). Membina Perkahwinan Berdaya Tahan Sepanjang Hayat melalui Pendekatan al-Quran dan al-Sunnah. Jurnal Pengajian Islam, Akademi Islam KUIS. 7(1), 174-187.

Edwards, R., Brock, T. B., Jonathon, K F., Adam, J. H., \& Michael, N. (2017). That's not what I meant: How misunderstanding is Related to Channel and Perspective-Taking. Journal of Language and Social Psychology. 36(2), 188-210. Doi:10.1177/0261927X16662968

Ekerbiçer, H. Ç., Sefa, R., Erkan, E., Mustafa, R. B., Özlem, A., Faruk, K., \& Can, B. (2016). A Comparison of Sexual Function, Psychological Status, and Sociodemographic Characteristics of Turkish Men within Polygamous and Monogamous Marriages. Balkan Medical Journal. 33(4), 383-389. Doi: 10.5152/balkanmedj.2016.16459

Esere, M. O., Ake-Y., \& Comfort, O. (2014). Obstacles and Suggested Solutions to Effective Communication in Marriage as Expressed by Married Adults in Kogi State, Nigeria. Procedia Social and Behavioral Sciences. 114, 584-592. Doi: 10.1016/j.sbspro.2013.12.751]

Farahmand M., \& Rezvani, Z. (2019). The Association Between Father's Power, Performance, and Mental Stress of First Wife in Monogamous and Polygamous Families: A Comparative Study in Iran. Iranian Journal of Psychiatry and Behavioral Sciences. 13(2), e85270. Doi: 10.5812/ijpbs.85270.

Fowers, B. J. (2001). The limits of a Technical Concept of a Good Marriage: Exploring the Role of Virtue in Communication Skills. Journal of Marital and Family Therapy. 27(3), 327340. Doi: 10.1111/j.1752-0606.2001.tb00328.x.

Green, A. I., Jenna, V., \& Barry, A. (2015). Marital Monogamy as Ideal and Practice: The Detraditionalization Thesis in Contemporary Marriages. Journal of Marriage and Family. 78(2), 416-430. doi: 10.1111/jomf.12277

Gumani, M. A., \& Tholene, S. (2009). The Experiences of Rural VhaVenda Women Involved in Polygamous Marriages. Journal of Psychology In Africa. 19(2), 199-205.

Hak, N. A. (2008). Just and Equal Treatment in Polygamous Marriage: The Practice in the Shariah Courts in Malaysia. IIUM Law Journal. 16(1), 141-155. https://doi.org/10.31436/iiumlj.v16i1.48

Hamzah, Z. A. Z., \& Ahmad, F. M. H. (2012). Penggunaan Strategi Ketidaksantunan dalam Kalangan Remaja di Sekolah. Jurnal Linguistik. 16(1), 62-74.

Henrich, J., Robert, B., \& Peter, J. R. (2012). The Puzzle of Monogamous Marriage. Philosophical Transactions of the Royal Society. 367(1589),657-669. doi10.1098/rstb.2011.0290

Honeycutt, J. M. (1994). Marital Happiness, Divorce Status and Partner Differences in Attributions about Communication Behaviors. Journal of Divorce \& Remarriage. 2(1-2) 177-206. doi: 10.1300/J087v21n01_10

Husain, R. T., Arifuddin, A., Siti Aisyah, K., \& Zulfahmi, A. (2019). Polygamy in the Perspective of Hadith: Justice and Equality among Wives in Polygamy Practice. MADANIA Jurnal Kajian Keislaman. 23(1), 93-104. Doi: 10.29300/madania.v23i1.1954

Ismail, F. (2016). Faktor Keharmonian dan Keruntuhan Rumah Tangga. In Kelestarian Dasar Awam, Daya Tahan Ekonomi dan Kesejahteraan Sejagat. Paper presented at Persidangan Kebangsaan Ekonomi Malaysia ke-11 (PERKEM ke 11), Hotel Bangi- 
Putrajaya, Selangor, Malaysia, 27-28 July 2016. Retrieved 2 January 2021 from http://eprints.uthm.edu.my/8396/1/PERKEM2016_2C6.

Ismail, N. M. (2001). Hubungan di antara Gaya Kepimpinan Ibu Bapa dengan Pelanggaran Disiplin Pelajar-Pelajar Tingkatan Empat di Sekolah Menengah Teknik Slim River, Perak. Master thesis, Kolej Universiti Teknologi Tun Hussein Onn, Johor, Malaysia.

Jonas, O. (2012). The Practie of Polygamy under the Scheme of the Protocol to the African Charter on Human and Peoples' Rights on the Rights of Women in Africa: A Critical Appraisal. Journal of African Studies and Development. 4(5), 142-149. doi 10.5897/JASD12.027]

Khasawneh, O. M., Abdul Hakeem, Y., \& Hijazi Nassmat, H. S. (2011). Polygamy and Its Impact on the Upbringing of Children: A Jordanian Perspective. Journal of Comparative Family Studies. 42(4), 563-577.

Kirsch, L. P., Charlotte, K., Nadia B., Laura, C., Valentina, M., Paul, M. J., \& Aikaterini, F. (2018). Reading the Mind in the Touch: Neurophysiological Specificity in the Communication of Emotions by Touch. Neuropsychologia. 116, 136-149. doi: 10.1016/j.neuropsychologia.2017.05.024.

Koktevdgaard, Z. M. (2008). Polygamy: A Cross Cultural Analysis. New York: New York University Press.

Krauss, R. M. \& Susan, R F. (1996). Social Psychological Models of Interpersonal Communication. In Social Psychology: Handbook of Basic Principles. Edited by E.T. Higgins and A. W. Kruglanski. (pp. 655-701), New York: The Guilford Press.

Lander, I. (2014). Utilizing Forgiveness Therapy to Heal the Negative Sequelae of Polygamous Family Structure Among Bedouin-Arabs: A Case Study of Treatment When the Injuring Party is Absent. Journal of Family Psychotherapy. 25(3), 246-264. Doi: 10.1080/08975353.2014.940784.

Lokman, M. A. A., \& Basri, I. (2017). The Development of the Terminology of al-Hikmah on the History of Usul al-Fiqh. International Journal of Academic Research in Business and Social Sciences. 7(6), 745-760. Doi: 10.6007/IJARBSS/v7-i6/3034

Marzuki. (1996). Beberapa Aspek Hukum Perkahwinan Islam di Indonesia, Mesir, dan Pakistan: Suatu Studi Perbandingan. Master thesis, IAIN Syarif Hidayatullah Jakarta, Indonesia.

Marx, M. H. (1976). Introduction to Psychology: Problems, Procedures, and Principles. New York: Macmillan.

McCarthy, B., Anna, T., \& M Moira, O. (2014). Integrating Psychology with Interpersonal Communication Skills in Undergraduate Nursing Education: Addressing the Challenges. Nurse Education in Practice. 14(3), 227-232. Doi: 10.1016/j.nepr.2014.01.008.

Mohamad, N. Z. A., Normi, A. M., Sofiah, S., \& Nazrul, A. J. (2019). Sustaining The Islamic Marriage Institution In Malaysia: Lessons From Qur'anic Stories. Al-Shajarah. 24(1), 97130.

Mohamed Ariffin, M. Y. (2007). Komunikasi Imam Shafie dalam Penyebaran Islam. Jurnal Pengajian Media Malaysia. 9(1), 125-136.

Mohd. Zin, A. A. (2003). Pengantar Dakwah Islamiah. Kuala Lumpur: Penerbit Universiti Malaya.

Muňiz-Velázquez, J. A., \& Alejandro, Á-N. (2013). Communication Serving Happiness. Vivat Academia. 124, 90-109.

Murry Jr, J. W., \& James, O H. (1995). Delphi: A Versatile Methodology for Conducting Qualitative Research. The Review of Higher Education. 18(4), 423-436. 
Nasution, K. (1996). Riba \& Poligami: Sebuah Studi atas Pemikiran Muhammad Abduh. Yogyakarta: Pustaka Pelajar.

Nikmah, H. S. (2011). Psikologi Komunikasi. Surabaya: Fakultas Dakwah dan Ilmu Komunikasi IAIN Sunan Ampel.

Nur Wahidah. (2011). Pola Komunikasi dalam Keluarga. Musawa. 3(2), 163-178.

Nuzula, F. (2015). Psikologi dan Komunikasi. El-Hikam Journal of Education and Religious Studies. 8(2), 403-420.

O'Shay-Wallace, S. (2020). We Weren't Raised that Way": Using Stigma Management Communication Theory to Understand How Families Manage the Stigma of Substance Abuse. Health Communication. 35(4), 465-474. Doi: 10.1080/10410236.2019.1567443.

Pickover, A. M., Thomas, S. D., Han, N. T., Alexandra J, L., \& J. Gayle, B. (2019). Factor Structure of the Communication Patterns Questionnaire in Violence-Exposed Women. Journal of Interpersonal Violence, 1-19. doi: 10.1177/0886260519867147.

Ponomaryov V. I., Osypenko, A. A., \& Lagniuk la, K. (2016). Communication Psychology. Manual in 2 parts. Part 1. Ministry of Education and Science of Ukraine: V. N. Karazin Kharkiv National University.

Predelli, S. (2004). Think before You Speak: Utterances and the Logic of Indexicals. Argumentation. 18(4), 445-463. Doi: 10.1007/s10503-004-4907-0

Radford, G. P. (1993). The Psychology of Communication or a Communicative Theory of Psychology? Reclaiming "Communication" as the Central Mode of Explanation for Communication Studies. Paper presented at the Annual Meeting of the Eastern Communication Association, New Haven, CT, April 28-May 2, 1993.

Rafeah, S., Hanifah, M. F. H., Zakiah, S., Fadhilah, A. I., \& Nur Zahidah, H. J. (2017). Regulating Polygamous Marriage to Prevent its Abuse: A Case Study of Malaysia. Pertanika Journal of Social Science and Humanities. 25(special Issue), 197-208.

Ahmad, R. R. M. (2017). Feeling of Inferiority Siswa Obesitas Berdasarkan Jenis Kelamin di SMPI Khaira Ummah Padang. Marwah: Jurnal Perempuan, Agama dan Jender. 16(1), 3255.

Rashidah, M., Saedah, S., \& Zaharah, H. (2018). Aplikasi Kaedah Fuzzy Delphi Dalam Pembangunan Modul Pengajaran Pantun Melayu Berasaskan Maksud Al-Quran Mengenai Keindahan Flora, Fauna Dan Langit Tingkatan 2. Jurnal Pendidikan Bahasa Melayu. 8(3), 57-67.

Rossi, P. (2019). Strategic Choices in Polygamous Households: Theory and Evidence from Senegal. Review of Economic Studies. 86(3), 1332-1370. Doi: 10.1093/restud/rdy052.

Sarji, A. (1985). Berucap untuk Khalayak Umum. Jurnal Komunikasi, Malaysian Journal of Communication. 1(1), 30-38.

Schramm, W. (1954). How Communication Works. In The Process and Effects of Mass Communication. Edited by Wilbur Schramm, (pp.3-26), Urbana, IL: University of Illinois Press.

Shannon, C. E., \& Warren, W. (1949). The Mathematical Theory of Communication. Urbana, IL: University of Illinois Press.

Siti Marziah, Z., Salina, N., Abdul Rahman, A. B., \& Nor Hazila, M. L. (2019). Kualiti Perkahwinan Pada Fasa Pertama Perkahwinan (1-10 Tahun): Pengaruh Gaya Komunikasi dan Penyesuaian Hidup. e-Bangi, Journal of Social Sciences \& Humanities.16(7), 1-11.

Slonim-Nevo, V., \& Alean, A. (2006). Success and Failure among Polygamous Families: The Experience of Wives, Husbands, and Children. Family Process. 45(3), 311-330. Doi: 10.1111/j.1545-5300.2006.00173.x. 
Steinberg, L., Susie, D. L, Nancy, D., Nina, S. M., \& Sanford, M. D. (1994). Over Time Changes in Adjustment and Competence among Adolescents from Authoritative, Authoritarian, Indulgent, and Neglectful Families. Child Development. 65(3), 754-770. https://doi.org/10.2307/1131416

Steyn, G. J. (2015). 'Think before you speak': The power of the tongue by Philo and James. HTS Theological Studies. 71(1), 1-7. https://dx.doi.org/10.4102/HTS.V71I1.3027

Strzalka, A. (2016). Can Earning Academic Credits be Enjoyable? Positive Psychology in a University Course of Intercultural Communication. In Positive Psychology Perspectives on Foreign Language Learning and Teaching. Second Language Learning and Teaching. Edited by Gabryś-Barker D., and Galajda D. (pp. 307-321), Springer, Cham. http://doiorg-443.webpn.fjmu.edu.cn/10.1007/978-3-319-32954-3_17

Sumakul, B. J. (2015). Peranan Komunikasi Keluarga Dalam Pembentukan Identitas Remaja Di Kelurahan Malalayang Kota Manado. e-journal "Acta Diurna". IV, 1-9.

Tang, C-W. \& Wu, C-T. (2010). Obtaining a Picture Of Undergraduate Education Quality: A Voice From Inside The University. Higher Education. 60, 269-286.

The Encyclopedia Americana. (1980). International Edition. Connecticut: Americana Corporation.

Thobejane, T. D., \& Takayindisa, F. (2014). An Exploration of Polygamous Marriages: A Worldview. Mediterranean Journal of Social Sciences. 5(27), 1058- 1066.

Thomas, C. E., Melanie, B-B., \& Steve, B-B. (1995). Perceptions of Deception, Divorce Disclosures, and Communication Satisfaction with Parents. Western Journal of Communication. 59(3), 228-245. doi: 10.1080/10570319509374519.

Thompson, P. (2008). Desperate Housewives? Communication Difficulties and The Dynamics Of Marital (Un)Happiness. Economic Journal. 118(532), 1640-1669. doi: 10.1111/j.14680297.2008.02184.x.

Van Buren, A. (2002). The Relationship of Verbal-Nonverbal In congruence to Communication Mismatches in Married Couples. North American Journal of Psychology. 4(1), 21-36.

Qarni, W. M. S., Isnaini, H., Sahkolid, N., \& Rahmah, F. (2019). Verbal and Nonverbal Factors Influencing the Success of Da'wah Communication by Ustadz Abdul Somad. Paper presented at The Second Annual International Conference on Language and Literature, Medan, Indonesia, July 3-4. Doi: 10.18502/kss.v3i19.4906

Wazir, R., Jamiurrashid, M., Rafiza, K., \& Khodijah, A. R. (2015). Komunikasi Dalam Islam Prinsip-Prinsip Berdasarkan Al-Quran dan As-sunnah. Hadis: Jurnal IImiah Berwasit. 10(1), 47-56.

Wan Mansor, W. N. H. (2014). Penerapan Unsur Kecindan dalam Proses Pengajaran dan Pembelajaran Reka Bentuk Teknologi. Master thesis, Universiti Tun Hussien Onn Malaysia.

Wood, C. W., \& Davidson, A. D. (2002). Emotional Skills and Stress: Parents' Stress Reduction Following PET Training in Empathic Listening, Non-Antagonistic Assertiveness and Family Conflict Resolution. Australian Journal of Psychology. 54, 64-64.

Xia, R. (2014). Correlation Analysis of College Students' Network Communication and Subjective Well-being-An Empirical Study Based on Social Psychology. Paper presented at the 2nd International Conference on Social Science and Health (ICSSH 2014), Taipei, Taiwan, May 31 Jun.

Xue, J., Kai, L., Ivan, Y. S., \& Jianhong, L. (2018). Information Communication Technologies and Intimate Partner Violence in China. International Journal of Offender Therapy and Comparative Criminology. 62(16), 4904-4922. doi: 10.1177/0306624X18801500. 
INTERNATIONAL JOURNAL OF ACADEMIC RESEARCH IN BUSINESS AND SOCIAL SCIENCES

Vol. 11, No. 4, 2021, E-ISSN: 2222-6990 @ 2021 HRMARS

Yaakob, N. A., Zainon, Z. A. H., Normaizura, M. Z., \& Syed Nurulakla, S. A. (2018). Penerapan Retorik dalam Penyampaian Ceramah Agama. Jurnal Linguistik. 22(2), 54-67. 